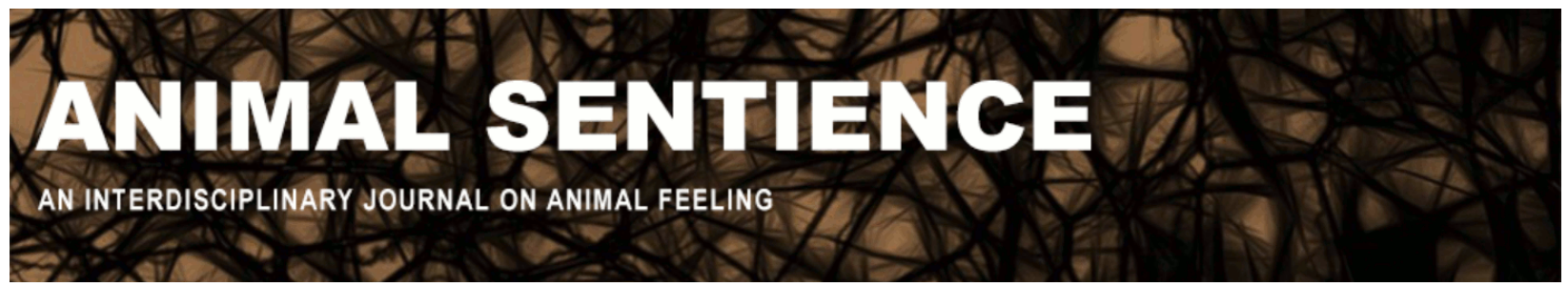

Levenda, Kelly (2017) Sensitizing humans to fish sentience. Animal Sentience 8(6)

DOI: $10.51291 / 2377-7478.1197$

Date of submission: 2017-03-01

Date of acceptance: 2017-03-07

(c) (†)

This article has appeared in the journal Animal

Sentience, a peer-reviewed journal on animal

cognition and feeling. It has been made open access,

free for all, by WellBeing International and deposited

in the WBI Studies Repository. For more information,

please contact

wbisr-info@wellbeingintl.org.

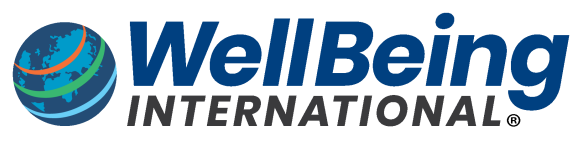

SOLUTIONS FOR PEOPLE, ANIMALS AND ENVIRONMENT 


\title{
Sensitizing humans to fish sentience
}

Commentary on Balcombe on Fish Knows

\author{
Kelly Levenda \\ Student-Programs Attorney, Animal Legal Defense Fund \\ Social Media and Website Contributor, Fish Feel
}

\begin{abstract}
Although fish can feel pain and suffer, they are not often protected legally. Jonathan Balcombe's What a Fish Knows provides a timely and important contribution to the literature on animal cognition and sentience. By explaining their personalities and capabilities, Balcombe brings much needed public attention to fish and advances the principle that they need and deserve protection.
\end{abstract}

Kelly Levenda, student-programs attorney at the Animal Legal Defense Fund, works to advance the emerging field of animal law and support the next generation of animal lawyers by managing Animal Legal Defense Fund's law student program. She is also a social media and website contributor at Fish Feel, which promotes the recognition of fish as sentient beings deserving of respect and protection.

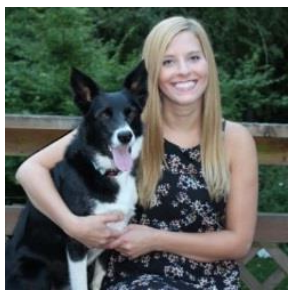
http://aldf.org/about-us/meet-our-staff/animal-law-program/\#kelly-levenda

Fish are capable of experiencing pain, fear, and suffering. We subject fish to inhumane slaughter, poor living conditions, and cruelty, as we do with land animals, yet we do not have even minimal measures to protect fishes' welfare. Without discussion and action, fish will continue to suffer greatly. We need to start bringing fish into our circle of compassion, not least because of the sheer numbers that are killed every year. The estimated total number of fish killed annually for consumption worldwide (based only on wild-caught and farm-raised finfish, not shellfish, such as lobsters, crabs, and shrimp) is one to three trillion (Mood \& Brooke, 2010). The fisheries capturetonnage statistics of the Food and Agriculture Organization of the United Nations - the data used in the estimate (Mood \& Brooke, 2010) - may be even higher than reported (Pauly \& Zeller, 2016). So this estimate may even be too low. Nor does it include fish who escape from fishing gear and may be fatally injured in the process, fish who are caught illegally, those who are caught as bycatch and discarded, those who are injured or killed by discarded fishing gear (ghost fishing), those who starve because of human competition for their food, or fatalities from any other unreported form of capture (Mood \& Brooke, 2010).

Fish are widely used in research and their use is expanding (Johansen, Needham, Colquhoun, Poppe, \& Smith, 2006). Almost two billion are caught by recreational anglers each year (Green, 2016). Vast numbers are bred in captivity or captured from the wild to be held in aquariums, zoos, or as companion animals (Green, 2016). Eleven million wild-caught tropical fish enter the U.S. every year as part of the aquarium trade (Bale, 2016). It is estimated that there are ten trillion fishes in the wild, all of whom could possibly suffer at the hands of human and nonhuman animals and nature (Green, 2016). 
We are morally obligated to protect fish from unnecessary pain. In the U.S., there are no federal or state laws that specifically pertain to fish welfare. Fish raised for consumption in the U.S. are not protected by the federal Humane Methods of Slaughter Act, which requires that animals be rendered unconscious before they are slaughtered; the 28-Hour Law, regulating the transportation of animals; or the Animal Welfare Act, which protects certain animals used for research and exhibition.

The suffering of fish is enormous. Fish on farms are intensively confined, which leads to fights and injuries. They suffer from diseases and parasites. Before transport to slaughter, fish can be starved for up to a month. During transport, they are removed from water, which is highly stressful for them, as they cannot breathe well in air and will eventually suffocate. When we catch fish from the wild, some are crushed by the weight of fish in the net. (Trawling nets can be as wide as a football field and longer than a three-story house!) Fish are snared by their gills and spiked with hooks (sometimes for hours or days). They are also impaled on hooks to be used as live bait.

As is also the case in the slaughter of land animals, egregious animal abuse has been shown at fish slaughter facilities. An undercover investigation showed employees slicing off fins, tearing the heads off, and peeling away the skin of fish who were alive and fully conscious. In commercial slaughterhouses, fish are often placed in water with dissolved carbon dioxide or ice water to render them immobile (but not unconscious) before slaughter. They are also routinely killed through live gutting, which can take up to an hour to render them insensible, and asphyxiation in air, which can take up to four hours to render them insenstient.

There are many ways that we can start to protect fish. Seafood certification programs, such as those from the Marine Stewardship Council and SeaChoice, are usually focused on "sustainable" fishing. Certification programs could include animal welfare standards, but no such program exists currently. We can pass legislation to regulate the use and slaughter of fish (although this is likely to be extremely difficult at the federal level, especially with the current administration.) We can extend the Humane Methods of Slaughter Act to cover fish, so they are rendered insensitive to pain before they are slaughtered. We can add fish to the U.S. Animal Welfare Act, so they receive some protections when they are being used as research subjects or on display at zoos and aquariums. We can regulate fishing methods and equipment to decrease the suffering of wild-caught fish. We can also refuse to support the fishing industry by not consuming their products.

Most of these actions to protect fishes will remain years away, as long as fish are given little, if any, consideration by humans, even within the animal protection community. No major animal protection organization focuses a large portion of its efforts on protecting fish. Of the major organizations, PETA seems to provide the most information about fish welfare and protection, with many webpages dedicated to aquaculture, fishing, captive fish, and experimentation. The Humane Society of the United States has completed white papers on Fish and Pain Perception and The Welfare of Farmed Fish at Slaughter. However, most of their other resources focus on keeping fish as companions. There have also been efforts by some organizations to document the inhumane treatment of fish. In 2010, Mercy for Animals did an undercover investigation at a commercial finfish slaughterhouse. In 2012, Animal Equality documented the yearly slaughter of tunas in Italy. Many wildlife organizations focus on sharks, but their focus is on conservation, not on decreasing suffering or protecting individual lives. 
There is one all-volunteer organization, Fish Feel, which is devoted exclusively to the recognition of fish as sentient beings who deserve respect and protection. I am hopeful that that recent focus of organizations like the Humane League, Mercy for Animals, and the Humane Society of the United States on chickens means that campaigns for fish protection will be next. The suffering of fish is also starting to gain attention from the legal community, with the new Aquatic Animal Law Initiative, part of the Animal Law Clinic of the Lewis and Clark Law School. The 2016 Animal Law Conference, presented by the Animal Legal Defense Fund, the Center for Animal Law Studies, and the Lewis \& Clark Law School's Student Animal Legal Defense Fund chapter, included a panel on Aquatic Animal Law. There has also been some movement on the legislative front. A coalition of nonprofits, including Fish Feel and Animal Legal Defense Fund, are working toward legislation to ban cownose ray killing contests in the Chesapeake Bay and its Maryland tributaries.

Fish need to be seen as animals worthy of protection. The public needs to be informed and sensitized about the evidence that fish can feel pain and suffer, that they are intelligent, have long-term memories, and can learn and remember complex information. Sympathy and empathy for fish also needs to be awakened by showing that they are cute, curious, playful, funny, and likeable. What a Fish Knows accomplishes all this and more.

Part One focuses on fishes' evolution, diversity, and versatility. Balcombe (2016a, b) notes that fishes' small relative brain size, which is often used against them, is a product of evolving in water. Living in a practically weightless environment means that there is no premium on limiting body size (relative to brain size). Fish benefit from having large, powerful muscles to propel themselves through water. Balcombe also mentions the many reasons fishes do not fall within our circle of moral concern. These include that we cannot relate to them as easily as other animals because they seem voiceless and we cannot detect their facial expressions. He also explains that we see fishes as "cold-blooded" and "primitive." But as we learn more about fish and their abilities, we relate to them more easily, and our empathy grows.

The purpose of Part Two is to put us in the fish's shoes (fins!). Balcombe discusses what a fish's sensory world is like, including how they see and experience the world. The fact that they are fooled by optical illusions shows that their mental experience of what they see is similar to ours. Although we often think of fish as silent, they actually create a symphony of sounds. They can vibrate their swim bladders, grate their teeth, stridulate their gill covers, and even rub bones together. Fishes have sensitive hearing to pick up all of these sounds. Balcombe also shares some stories from guardians who believe their fishes try to use sound to communicate with them, by banging on their tanks, making smacking sounds with their mouths, and rapping on the side of their tank with a pebble.

Fishes also have good senses of smell and taste (some even have taste buds outside their mouth and throat). They have senses that humans do not have, such as detectors of the Earth's magnetic field to navigate and pressure sensors to track movements of those nearby. Some can even perceive electrical stimuli and produce their own electrical charges. Fishes are also highly sensitive to touch. It may be surprising to some, that like us, they derive pleasure from the sensation of someone touching them. Fishes touch each other when courting and sometimes receive a caress from a cleaner fish as he is doing his job picking parasites off of them. Balcombe shares stories of companion animals and wild fish who enjoy being petted. 
In Part Three, we learn about the feelings of fish. This is one of the most important parts of the book because I believe Balcombe's discussion of the latest research demonstrating that fish can feel pain and suffer has the potential to shape public perception. Evidence that fish are sentient is imperative in the fight to protect them. We know that fish have the receptors to detect noxious stimuli, but there is debate over whether and what they feel in response to what these receptors detect.

The main argument that fish cannot feel pain is human-centric: because they do not possess the same part of the brain (the neocortex) that controls our cognitive response to pain, that means they cannot feel pain (Key, 2016). This argument fails for many reasons. Only mammals have a neocortex, yet there is a scientific consensus that nonmammals, such as birds, can feel pain. This argument ignores comparable structures in the fish brain, like the pallium. (Brain parts can be anatomically different, but functionally similar.) There is also behavioral evidence that fish feel pain. After fish are caught, they may show "hook shyness" and avoid fishing gear and hooks. When fish were injected in the lips with vinegar and bee venom, their gills beat faster, they did not show interest in food, they rocked side to side, and they rubbed their lips on the side of their tank. After they were given painkillers, these negative reactions decreased. In other experiments, fish who were injected and in pain could not perform normal survival behaviors like avoiding a new object in their environment. Fish also paid a price to receive pain relief, as they chose a barren tank with a dissolved painkiller over the enriched tank that they usually prefer. The weight of the extensive evidence of pain perception in fish is strong, and suggests that we are morally obligated to protect them from unnecessary pain.

Balcombe also addresses the emotions of fish. They can feel a range of emotions, from compassion, pleasure, and playfulness to fear, depression, anxiety, and stress. Fish show compassion when they help their friends. Balcombe shares an anecdote of a fish who assisted his disabled friend by swimming beneath him, which allowed him to swim more normally. Fish derive pleasure from playing (with objects, other fish, and even other species). Balcombe also shares an anecdote about a game between a fish and cat, where the cat repeatedly tries to get a lick of water from the fish's tank before the fish notices and swims quickly toward the cat.

Fish respond to predators in a way that we expect animals who feel frightened to respond: they breathe faster, flee, freeze, or try to look bigger. In one experiment, fishes who were depressed sank to the bottom of their tank and didn't move. Their depression and anxiety were relieved with Valium and Prozac. Similar to humans, when fishes are stressed, a nice caress helps them relax. It is important that people know that not only can fish feel physical pain, but they also can suffer emotionally. This makes our ethical duty to protect them even more important.

Part Four delves into fish's intelligence. Humans often measure an animal's intelligence by comparing it to our own. This is a self-centered way to think because intelligence is shaped by the tasks a species needs to be able to perform to survive in its environment. Fish live in a very different environment from humans, so it is likely that they have different mental abilities. This doesn't make them diminished, just different. I think it is nevertheless useful to demonstrate to people that fish are intelligent (even if in different ways from us), because it shows that they are complex beings. And although I don't believe in measuring intelligence by comparing species, showing people that fish have abilities similar to those of the animals they are fond of (such as dogs, cats, or charismatic wild animals) or the animals they consider very intelligent (like primates), makes it easier to relate to them, and like them. 
Contrary to the "three-second memory" myth, many fish have excellent memories. For example, Frillfin gobies frequent tidal pools. If a predator arrives, they need to make a quick escape by jumping into a nearby pool. In order to do this, they memorize the topography of the intertidal zone so they know where other pools are located. Fish are also great learners. They can innovate to solve problems and even use tools.

In Part Five, we learn about the social lives of fish. They recognize other fish (and humans too!) and have friendships and partnerships. Their social interactions are influenced by their personalities; some are curious, some are shy, and some are sweet. Balcombe discusses one of the most intensely studied and complex social systems in nature: the relationship between cleaner fish and their clients. Cleaner fish remember their clients (they can have up to 2,297 a day!) and when that client's last appointment was. They communicate with their clients and show them consideration. (They tend to give better treatment to new and predacious clients and to fish who live near their home and are therefore more likely to be run into again.) Along with crows, elephants, and orcas, cleaner fish transmit behaviors socially, which means they have culture. Another social relationship that Balcombe mentions is that of the grouper and eel who hunt together cooperatively using referential gestures. Fish even appear to have democracy. They make decisions collectively and choose leaders to follow. Again, the evidence that fish have social lives and friendships, cooperate, and are democratic, like us, might sensitize our species to their vulnerability and welfare needs.

In Part Six, Balcombe details fishes' sex lives and parenting techniques. Like many other animals, fish have courtship rituals, including dances, artistic creations, love songs, and touches. Some fish manipulate or deceive others into mating with them. Fishes are protective parents, safeguarding their eggs and carrying eggs or baby fish in their mouths. I don't think many would be surprised to learn of these behaviors, as many animals protect their children.

Balcombe hits us with the hard facts about the abuse of fish used for consumption in Part Seven. The average American consumes about forty pounds of fish a year. Fish consumption is growing dramatically in the two most populous nations, China and India. Trillions are killed every year in horribly inhumane ways. For example, a single purse seine net can contain a hundred thousand mackerels or half a million smaller fish like herrings. When caught in nets, fish are crushed under the weight of others. Fish taken from deep water suffer from decompression effects, such as parts of their gut forced out through their mouths and anuses, burst swim bladders, and their eyes bulge out of their sockets. If a fish is caught in a net or on a hook on a long line, they can suffer there for days, vulnerable to predators' attacks. Once fish are brought on the boat, they usually die from suffocation.

We are literally emptying the oceans of fish and decimating other organisms in their environment to catch them. There are many innocent bystanders who are also caught and killed during fishing, including turtles, birds, dolphins, and whales. It is hard to estimate the number of animals killed as bycatch every year because much of it is unreported. The daily bycatch is estimated to be 200 million pounds of animals! Shrimp fisheries are the greatest offenders. Their bycatch ratios have been estimated to be up to three times the amount of their shrimp catch! Many nets and hooks are also lost or left in the ocean, and continue to snare and kill animals for years.

Farming fish won't be able to save wild fish populations. This is because the majority of fish on farms are fed fishmeal (which is made from wild-caught fish) and farmed fish eat more in 
fish protein than they produce. Fish farming in the open ocean is detrimental to the environment. Parasites escape and infect wild populations. Waste from the fish and chemicals used to treat parasites and diseases contaminate surrounding water.

Farming fish is also cruel. Farms accept death rates ranging from ten to thirty percent. Like other animals on factory farms, fish are kept in intensive confinement, where parasites, diseases, and infections thrive. Sea lice, which feed on the mucus, flesh, and eyes of fishes, are common on farms. In addition, the ways farmed fish are killed cause them great suffering. They are gutted alive, decapitated, put in salt, ammonia, or carbon dioxide baths, or live chilled.

I think Part Seven may be the most important chapter in the book. Many do not know the horrors associated with farming or catching fish, as this information is not readily available. Making this information mainstream knowledge would go far in helping animal advocates protect fish. The members of our species need to (1) learn that fish can feel pain and (2) learn that they are likable, so that we can feel empathy for them and thereby (3) realize the horrors they experience when we use them for food, entertainment, or research. Jonathan Balcombe's book teaches us all three things. It will help to sensitize society to the welfare needs of fish. I hope we will see many more books, articles, and documentaries on fish and their abilities in the near future, so they can finally receive the consideration and protection they desperately need and deserve.

\section{References}

Balcombe, J. (2016a). What a fish knows: The inner lives of our underwater cousins. New York: Farrar, Straus and Giroux.

Balcombe, J. (2016b) In praise of fishes: Précis of What a fish knows (Balcombe 2016). Animal Sentience 8(1)

Bale, R. (2016). The horrific way fish are caught for your aquarium - with cyanide. National Geographic, 10 March. news.nationalgeographic.com/2016/03/160310-aquarium-saltwatertropical-fish-cyanide-coral-reefs. Accessed March 3, 2017.

Green, C. (2016). Animal advocacy by numbers. Faunalytics.org, 15 July. faunalytics.org/animaladvocacy-by-numbers. Accessed March 3, 2017.

Johansen, R., Needham, J., Colquhoun, D., Poppe, T., \& Smith, A. (2006). Guidelines for health and welfare monitoring of fish used in research. Laboratory Animals, 40(4), 323-340.

Key, B. (2016) Why fish do not feel pain. Animal Sentience 3(1)

Mood, A. \& Brooke, P. (2010). Estimating the number of fish caught in global fishing each year. Fishcount.org.uk, July 2010. fishcount.org.uk/published/std/fishcountstudy.pdf. Accessed March 3, 2017.

Pauly, D. \& Zeller, D. (2016). Catch reconstructions reveal that global marine fisheries catches are higher than reported and declining. Nature Communications, 7. doi:

$10.1038 /$ ncomms10244 